Journal of Clinical Investigation

Vil. 41, No. 12,1962

\title{
THE MEASUREMENT OF CEREBRAL BLOOD FLOW BY EXTERNAL ISOTOPE COUNTING *
}

\author{
By SHELDON H. STEINER, $\dagger$ KWAN HSU, LEO OLINER, AND ROY H. BEHNKE \\ (From the Medical and Radioisotope Services, Veterans Administration Hospital, and the \\ Department of Medicine, Indiana University School of Medicine, \\ Indianapolis, Ind.)
}

(Submitted for publication December 22, 1961 ; accepted September 1, 1962)

The Kety-Schmidt nitrous oxide method (2) is presently the only well-accepted technique for the quantitative estimation of human cerebral perfusion. In spite of theoretical objections (3) and practical limitations it has provided a wealth of otherwise unobtainable information. The procedure is tedious, however, and has remained predominantly a laboratory research tool.

Efforts have continued to find an accurate, more adaptable method, but with limited success. Sapirstein and Hanusek (4-6) have reported measurements of regional blood flow in laboratory animals by use of $\mathrm{K}^{42}, \mathrm{Rb}^{86}$, and 4-iodo ${ }^{131}$ antipyrine, and Sapirstein has reported observations concerning the applicability of these materials to measurement of human cerebral perfusion $(7,8)$. This investigation was designed to evaluate, clarify, and extend those observations by employing 4-iodo ${ }^{181}$ antipyrine and $\mathrm{Rb}^{86} \mathrm{Cl}$ in the quantitative estimations of human cerebral blood flow. The effects of altered arterial $\mathrm{pCO}_{2}$ upon cerebral hemodynamics were evaluated by use of this research method.

\section{THEORETICAL CONSIDERATIONS}

Regional blood flow by indicator distribution. After a rapid intravenous injection of an indicator substance, mixing occurs during passage through the central circulation. The initial distribution throughout the body is directly proportional to the regional distribution of the cardiac output. The problem inherent in this method of determining organ blood flow is that of quantifying the

* Supported by U. S. Public Health Service Grants H4080, H6308, and HTS5363 from the National Heart Institute, and by the Indiana Heart Association. Presented in part before the 34th Annual Meeting of the Central Society for Clinical Research, Chicago, Ill., November, 1961, and published in part (1).

$\dagger$ VA Clinical Investigator. fraction of injected indicator received by an organ during this first circulation. It would be fortunate if a substance existed that could be totally extracted by each organ through which it passed; problems dealing with recirculation would be avoided. With such a substance, organ content would increase as the arterial bolus was delivered, and since venous drainage of the substance would be zero, the organ content after initial localization would be independent of time. In that case the fractional organ uptake of the injected dose would be proportional to the fractional organ distribution of the cardiac output. Sources for error in this theoretical system would be the presence of pulmonary indicator losses and arteriovenous shunts.

It would be possible to make measurements of regional blood flow, however, if the substance became redistributed sufficiently slowly after initial localization. This might allow extrapolation of the organ washout rate back to maximal organ content at zero time of initial delivery. Sapirstein (4) has reported that the net redistribution rate for $\mathrm{K}^{42}$ and $\mathrm{Rb}^{86}$ after initial localization of a bolus injection for most organs of the rat and dog is slow enough not to be statistically detectable for 3 minutes. The applicability of these isotopes to measurement of regional blood flow probably depends on the nature of the distribution of body potassium and the rate of membrane ion transport. Walker and Wilde (9) have demonstrated that the injected isotope bolus of $\mathrm{K}^{42}$ of high specific activity, which is initially diluted in a relatively small blood volume, is to a large degree lost from the vascular compartment after the first circulation has washed through. Since the organ content is initially zero and the arterial bolus concentration is high, the tracer is transferred chiefly into the organ pool, since it is considerably larger than the vascular reservoir for potassium. Most 


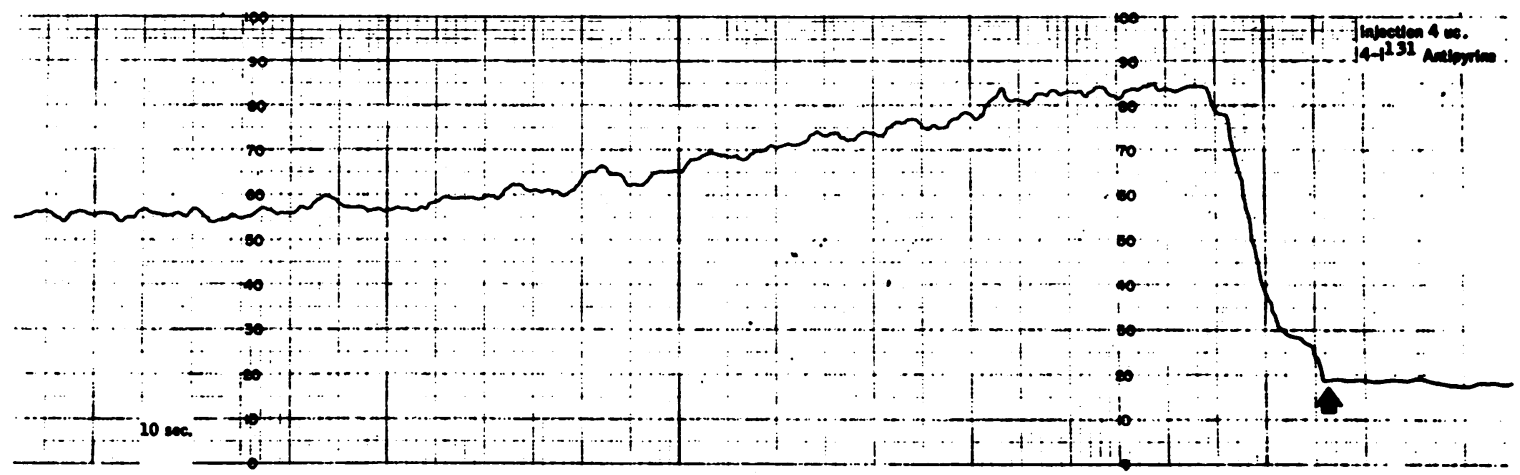

Fig. 1. The cephalic 4-IOdo ${ }^{131}$ antipyrine count rate after a rapid central venous injection.

of the radioactivity is rapidly cleared from the circulation, and the remainder is diluted. Net redistribution is slow, and for a considerable period after the first circulation of the bolus, the organ fraction of the injected dose reflects the fractional organ distribution of the cardiac output. The washout curve approaches a relatively horizontal line.

The major objection to this method for measuring regional blood flow in animals is that the entire time-course of localization cannot be viewed. since the organs must be removed for counting purposes. Early redistribution from regions with small exchangeable pools-e.g., brain-or from arteriovenous shunts give falsely low flow fractions for these organs. Conversely, there are false increases in the flow fractions to organs with large exchangeable pools, owing to the redistribution of the tracer out of proportion to the initial distribution of the cardiac output. This objection would be removed if the organ content could be continuously observed during accumulation of the tracer (10). In that case, early redistribution could be detected and possibly corrected for by extrapolation.

Cerebral blood flow. The principles of this method have been applied to the quantification of human cerebral blood flow $(1,7,8)$. In order to measure uptake by an organ of a radioisotope in vivo, it is necesary to observe the organ quantitatively with appropriate detectors. Gamma emission from the human brain has not been satisfactorily separated from that of adjacent noncerebral cephalic structures. For the present, therefore, it has been necessary to determine cerebral blood flow from the difference between the total cephalic flow-brain, head, and neck-and the noncerebral cephalic flow-head and neck. 4-Iodo ${ }^{13}$ antipyrine and $\mathrm{Rb}^{86} \mathrm{Cl}$ have been used to measure total cephalic blood flow and noncerebral cephalic blood flow, respectively.

Total cephalic blood flow. Sapirstein and Hanusek (6), Hansen (11), and Reinmuth and Scheinberg (12) have reported that 4 -iodo ${ }^{131}$ antipyrine readily crosses the "blood-brain barrier." During the first circulation after a venous injection of 4 -iodo ${ }^{131}$ antipyrine, the quantity delivered to the head represents the cephalic fractional distribution of the cardiac output. There is a reasonably large, exchangeable, cephalic reservoir for the isotope, and the washout rate after initial localization is relatively slow (Figure 1; the rate meter time constant is 2.0 seconds).

The arteriovenous differences for 4-iodo ${ }^{131}$ antipyrine were determined in two subjects in order further to elucidate the nature of the cephalic distribution and washout of the isotope. Samples were taken from the brachial artery and the internal jugular vein by retrograde arm vein catheterization with fluoroscopic placement of the catheter tip just cephalad to the junction with the subclavian vein at the base of the neck. At this point the internal jugular vein has received a major portion of the venous drainage from the head and neck (13). The arterial and venous concentration changes with time are shown for one of these subjects during the minute and a half after central venous (superior vena cava) injection (Figure 2). The arterial concentration describes an indicator dilution curve. The venous curve gradually increases during the first circulation, and it then remains slightly above the arterial concentration 
during the subsequent minute of observation. The venous blood demonstrates significant concentration of label during the period of observation, and this accounts for the early redistribution of the cephalic 4-iodo ${ }^{131}$ antipyrine. A large portion of the tracer delivered by the arterial blood is retained by the head, and redistribution is relatively slow.

Mathematical model. Since significant cephalic washout of 4-iodo ${ }^{131}$ antipyrine-approximately 15 to 20 per cent-occurs during initial localization. it is necessary to compute the value for cephalic content existing before washout has occurred. In order to make this calculation, a model has been devised that requires several simplifying assumptions. The heart is represented by a single chamber of fixed volume whose contents are uniformly and instantly labeled at the moment of injection. Flow of blood through the chamber is constant for the period of observation. A portion, $A_{0}$, of the uniformly labeled pool at zero time is destined for the head. The quantity of label in the heart destined for the cephalic structures at time $t$ is $A_{1} t$. From this is derived Equation 1,

$$
d A_{1} / d t=-K_{1} A_{1}(t \geq 0) .
$$

The head is assumed to be a single, fixed-volume mixing chamber that accumulates indicator as it leaves the heart. Distortion imposed by passage through the arteries leading to the head is considered negligible. Consequently, cephalic uptake can be represented as a first-orcler exponential function.

However, the experimental observations (Figure 1) show significant washout during localization. This is assumed to follow a first-order exponential function. The rate of change of cephalic

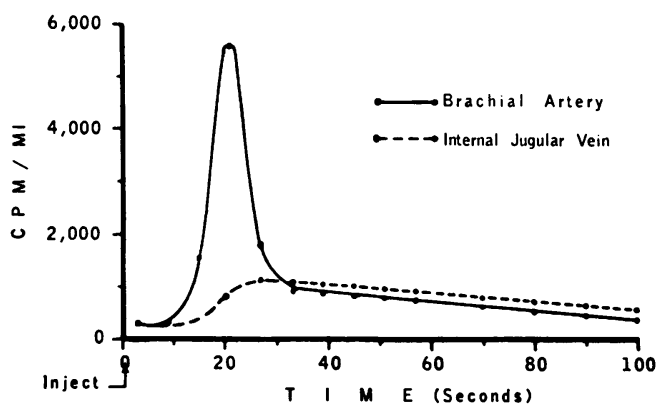

Fig. 2. Brachial arterial and internal Jugular VENOUS CONCENTRATIONS OF 4-IODO ${ }^{131}$ ANTIPYRINE AFTER A $4 \mu$ C RAPID CENTRAL VENOUS INJECTION.

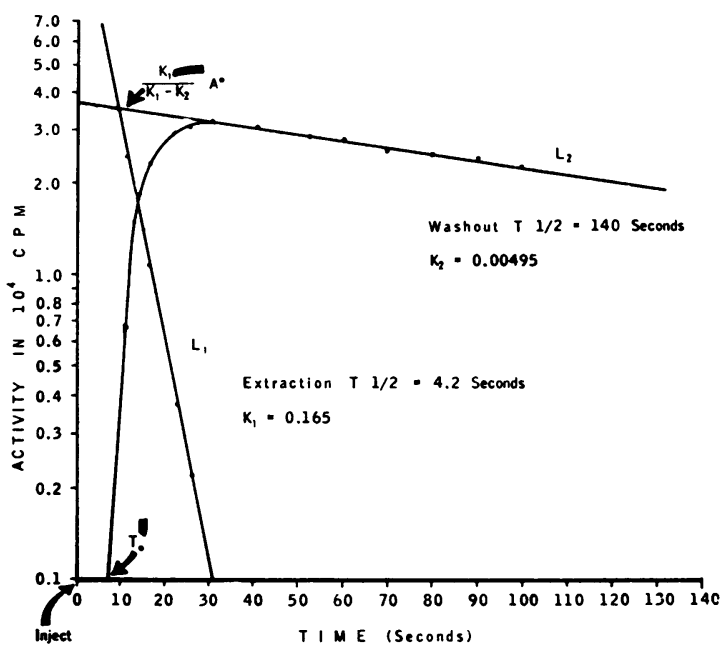

Fig. 3. Semilogarithimic plot of ObServed CePhalic CONCENTRATION DATA FOR 4-IODO ${ }^{131}$ ANTIPYRIDINE AFTER A RAPID CENTRAL vENOUS INJECTION. Extrapolation of washout portion of curve is represented by the line $\mathrm{L}_{2}$. The difference between the extrapolated portion of $\mathrm{L}_{2}$ and the buildup portion of the cephalic concentration data is represented by the line $\mathrm{L}_{1}$. $\mathrm{T}_{0}$ is the time of appearance in the head of label.

indicator, $A_{2}$, can then be represented by the difference between first-order exponential functions. The amount of indicator in the head at zero time is given by $A_{2}=0$ and at time $t$ by $A_{2} t$ so that by Equation 2,

$$
d A_{.2} / d t=K_{1} A_{1}-K_{2 .} A_{.2}(t \geq 0) .
$$

Solution of Equation 1 gives Equation 3.

$$
A_{1}=A_{0} e^{-K_{1} t} \quad(t \geq 0),
$$

and so'ution of Equation 2 gives Equation 4,

$$
A_{2}=\left[K_{1} / K_{1}-K_{2}\right]\left[A_{0}\left(e^{-K_{\mathrm{v}} t}-e^{-K_{1} t}\right) \mid(t \geq 0) .\right.
$$

Where $K_{2}$ « $K_{1}$, Equation 4 gives Equation 5 .

$$
\underset{t \rightarrow \infty}{\operatorname{limit}_{t \rightarrow} A_{2}}=\left(K_{1} / K_{1}-K_{2}\right) A_{0} e^{-K_{2} t} .
$$

This equation is represented by the line $\mathrm{L}_{2}$ in Figure 3.

The quantity of label delivered to the head, $A_{0}$. can be determined graphically from the difference between two exponential functions. Equation 4 subtracted from Equation 5 gives Equation 6,

$$
Q=\left(K_{1} / K_{1}-K_{2}\right) A_{0} e^{-K_{1} t},
$$

where $Q t$ is an approximation of the cardiac label still to be delivered to the head at time $t$ and is represented in Figure 3 by the line $L_{1}$. 
When $t=0, L_{1}$ intercepts $L_{2}$ at the coordinate $K_{1} A_{0} / K_{1}-K_{2}$; for values of $K_{1} \gg K_{2}$, its value is not very different from $A_{0} . A_{0}$ may be found by determining $K_{1}$ and $K_{2}$ from a semilogarithmic plot of the observed data (Figure 3). The effects of recirculation of label are assumed to be negligible.

Critique of the model. This simplified model has several advantages. It allows for a consistent and reproducible method of fixing the value for cephalic indicator content. This method eliminates the need for bilateral jugular cannulation, which would otherwise be required to make the determination of cephalic blood flow by use of the conventional Fick equation. In the situation where indicator loss from the heart is delayed or where cerebral blood flow is large, the values for $K_{1}$ and $K_{2}$ may not be so very different. The model then provides a means graphically to determine cephalic content from $K_{1}, K_{2}$, and the coordinate $K_{1} A_{0} / K_{1}-K_{2}$.

In Figure 3, the appearance of label in the head does not occur at zero time as set forth in the model. The appearance is actually a finite number of seconds after injection and has been designated $t_{0}$. If there were no distortion or dispersion of the tracer during transit from injection site to appearance site, the time required for it to traverse the vascular system would be immaterial. Since $K_{1}$ is so much greater than $K_{2}$, an error introduced in the value of $K_{1}$ by distortion or dispersion would not be expected significantly to alter the determination of $A_{0}$.

The model assumes cephalic washout is a firstorder exponential function. Since $K_{1} » K_{2}$, the contribution from the term $\left(-K_{1} / K_{1}-K_{2}\right)$ $A_{0} e^{-K_{1} t}$ of Equation 4 is transient, and the slope of the washout $\mathrm{K}_{2}$ ought to be a function solely of the disappearance of indicator from the head very shortly after peak concentration has been achieved. A semilogarthmic plot of the washout (Figure 3 , line $L_{2}$ ) is a straight line, verifying the assumption of the first-order exponential nature of the washout slope. Caution must be exercised, however, to insure that the time constant of the detecting apparatus is sufficiently short to respond to early exponential cephalic washout having a different rate constant. With time constants as short as 0.5 second, early cephalic indicator washout was not observed to follow an exponential curve different from that of the major decay component. A 2-second time constant did not alter the curves, but served to minimize random counting fluctuations, simplifying the graphical plot.

Recirculation of indicator was considered to be negligible during the period of experimental observation. The volume of distribution of 4-iodo ${ }^{131}$ antipyrine during the first minute after injection was found to be somewhat greater than $20 \mathrm{~L}$. This volume is roughly four times greater than

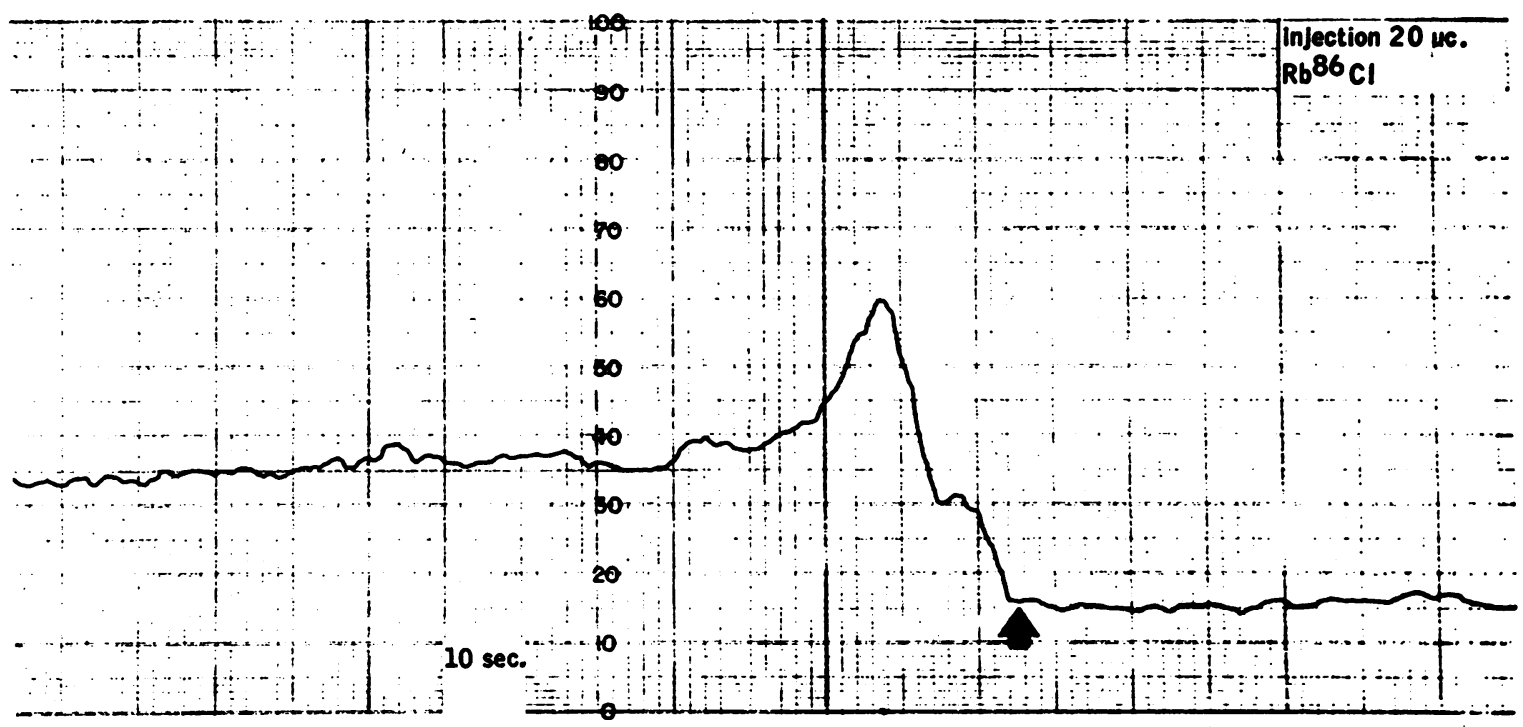

Fig. 4. The Cephalic $\mathrm{RB}^{80} \mathrm{Cl}$ count rate after a Rapid central venous injection. 
that of the vascular compartment. In addition, the initial bolus is delivered in a volume considerably less than the total vascular volume. Therefore, the contribution from recirculating label at any time must represent only a small portion of the amount initially delivered to the cephalic compartment.

The error introduced for the value of the cephalic portion $A_{0}$ of the cardiac indicator by use of the value for $K_{1} A_{0} / K_{1}-K_{2}$ was found to be 2.5 \pm 0.4 per cent in 9 experiments in 5 subjects. This was considered to be sufficiently good for the purposes of this investigation. If greater accuracy is required, $A_{0}$ could be determined from the coordinate $K_{1} A_{0} / K_{1}-K_{2}$, and from the values obtained for $K_{1}$ and $K_{2}$ by standard methods for analysis of the semilogarithmic plot of the observed data.

Noncerebral cephalic blood flow. The noncerebral cephalic fraction of the cardiac output is determined from an injection of $\mathrm{Rb}^{86} \mathrm{Cl}$. After a rapid central venous injection of the label, the cephalic count rate describes an indicator dilution curve (Figure 4), and then a plateau for a considerable time. Since there is virtually no readily exchangeable cerebral reservoir for cationic materials, the indicator dilution pattern seen initially represents shunting of the isotope through the brain. There is, however, a large, rapidly exchangeable reservoir for $\mathrm{Rb}^{86}$ in non-nervous tissue $(5,9)$, and after the first circulation has washed through, the residual cephalic plateau is greater than 10 per cent of the injected dose. This probably does not represent an appreciable number of counts from the vascular compartment, since the apparent minute volume of distribution averages somewhat more than $60 \mathrm{~L}$, and cephalic blood volume appears to be relatively small. The stable cephalic plateau, therefore, represents the approximate noncerebral cephalic fraction of the cardiac output.

Two problems exist in the interpretation of the exact nature of the cephalic $\mathrm{Rb}^{86}$ plateau after initial localization of the injected dose. The first is, to what extent there exists a cerebral $\mathrm{Rb}^{86}$ reservoir that may contribute to the total count rate. Sapirstein suggests (8) that the normal human brain has a very small reservoir for $\mathrm{K}^{42}$, and indeed he suggests that the reservoir may be con-

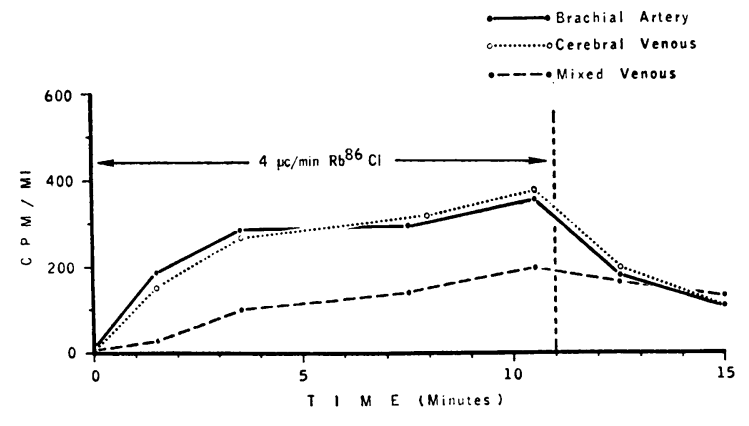

Fig. 5. Constant pulmonary artery infusion of $\mathrm{RB}^{88} \mathrm{CL}$.

fined to the non-nervous elements. The reservoir for $\mathrm{Rb}^{86}$ is very small in normal subjects. It has not been possible to demonstrate significant cerebral uptake of $\mathrm{Rb}^{86}$ in man by measuring the cerebral arteriovenous difference during a 10-minute constant infusion (Figure 5). Mealey, Sweet, and Brownell (personal communication) report that normal human brain, biopsied within $15 \mathrm{~min}$ utes after rapid intravenous injection of $\mathrm{Rb}^{86}$, contains $0.25 \pm 0.3$ per cent per $\mathrm{kg}$ of the injected dose in the cerebrum in 5 subjects. In a total of 35 samples taken from 14 patients up to 180 minutes after injection, the maximal value of $0.4 \pm$ 0.3 per cent per $\mathrm{kg}$ was seen during the third hour. The cephalic $\mathrm{Rb}^{86}$ fraction would then be overestimated by slightly less than 0.5 per cent of the injected dose. No correction was made for this residue.

The second major objection to this method for determining regional blood flow is the large cerebral shunt for $\mathrm{Rb}^{86}$, i.e., the effects of arteriovenous shunts upon the redistribution of the injected dose out of proportion to the initial distribution of the cardiac output. It is readily seen from the cephalic $\mathrm{Rb}^{86}$ count rate (Figure 4) that the brain represents a substantial shunt whose $\mathrm{Rb}^{86}$ content must be redistributed to organs with exchangeable pools during subsequent circulations. Sheppard, Overman, Wilde, and Sangren (14) have reported that in the dog the major organs except for the brain-liver, kidney, and extremity-exhibit little shunting for $\mathrm{K}^{42}$. Thus, the material recirculated from the brain probably makes up the greatest portion of the total body shunt. In that case, the noncerebral cephalic fraction of the cardiac output is overestimated by the fraction of $\mathrm{Rb}^{86}$ redistributed to it from the $\mathrm{Rb}^{86}$ shunt in propor- 


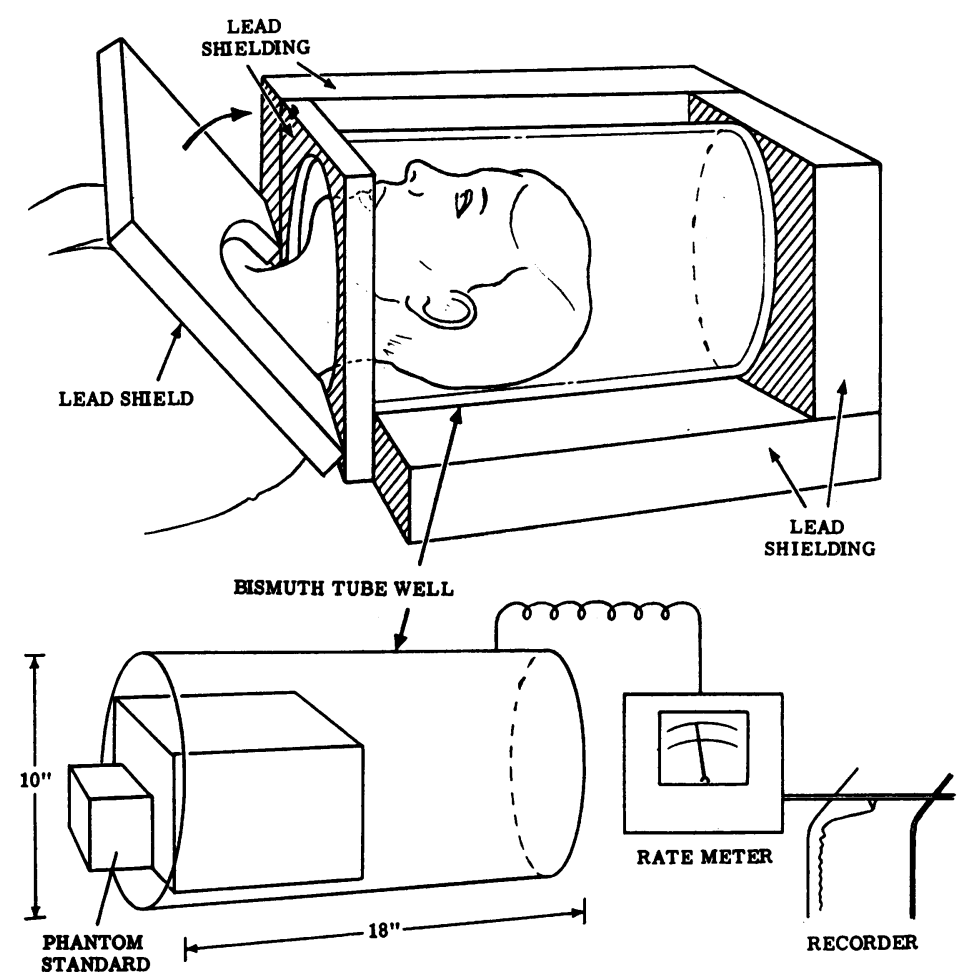

Fig. 6. Schematic Representation of Cephalic Counter ANd head SHIELD; CALIBRATING PHANTOM SHOWN IN THE LOWER INSERT.

tion to the noncerebral cephalic blood flow. It was assumed that the only major shunt different for $\mathrm{Rb}^{86}$ and 4-iodo ${ }^{131}$ antipyrine was represented by the brain. Therefore, the noncerebral cephalic blood flow is the cephalic fraction of the injected $\mathrm{Rb}^{86}$-less the cerebral $\mathrm{Rb}^{86}$ residue, assumed to be zero for this investigation-multipled by the cardiac output, and is overestimated by the redistribution of the cerebral flow fraction to noncerebral cephalic structures in proportion to the noncerebral cephalic flow. Cerebral blood flow is the difference between the total cephalic blood flow-determined from the zero-time maximal content of the cephalic 4-iodo ${ }^{131}$ antipyrine multiplied by the cardiac output-and the noncerebral cephalic fraction, multiplied by cardiac output and corrected for the recirculation of $\mathrm{Rb}^{86}$ from the brain shunt to the noncerebral cephalic structures in proportion to the noncerebral cephalic blood flow. Sapirstein's report (8) that this can be solved as a simultaneous equation is repeated here for continuity. Where $F_{t}=$ cephalic blood flow, $F_{m}=$ noncerebral cephalic blood flow, $F_{B r}=$ cerebral blood flow, C.O. = cardiac output, $F_{r} I^{131}$
$=$ cephalic fraction of 4 -iodo ${ }^{131}$ antipyrine determined from zero time extrapolation of the cephalic count rate, $F_{r} R b^{86}=$ cephalic fraction of $\mathrm{Rb}^{88} \mathrm{Cl}$, and $F_{r_{B r}}=$ cerebral flow fraction of the C.O.

$$
\begin{gathered}
F_{r} I^{131} \cdot \text { C.O. }=F_{B r}+F_{m}=F_{t} \text { and } \\
F_{r} R b^{86} \cdot \text { C.O. }=F_{m}+F_{m} \cdot F_{r_{B r}} .
\end{gathered}
$$

These equations are solved as a quadratic function,

$F_{B r}=$

$$
\left[\frac{\left(F_{r} I^{131}-1\right)+\sqrt{\left(1-F_{r} I^{131}\right)^{2}+4\left(F_{r} I^{131}-F_{r} R b^{86}\right)}}{2}\right] \text { C.O. }
$$

\section{EXPERIMENTAL METHODS}

Protocol. Sixteen male patients 20 to 40 years of age, in the postabsorptive state, without premedication, and with minor illnesses, served as subjects. A venous catheter was placed into the superior vena cava, and a brachial arterial needle was inserted. Each subject rested with his head inside the well detector for at least 30 minutes before the measurements were made. Control measurements were made in all subjects, and replicate measurements in $1 / 3$ of the group. In the remainder, arterial $\mathrm{pCO}_{2}$ was altered either by voluntary hyperventilation or by breathing 5 per cent $\mathrm{CO}_{2}$ in air for 10 minutes; measurements were then repeated. 
Isotopes. Approximately $20 \mu \mathrm{c}$ of $\mathrm{Rb}^{86} \mathrm{Cl}^{1}$ of high specific activity in $2 \mathrm{ml}$ isotonic saline was injected and the count rate recorded for $2 \mathrm{~min}$. Four to $6 \mu \mathrm{c}$ of 4-iodo ${ }^{131}$ antipyrine ${ }^{1}$ in $2 \mathrm{ml}$ isotonic saline was then injected and the count rate recorded. ${ }^{2}$

The purity of the 4-iodo ${ }^{131}$ antipyrine was checked by a paper chromatographic separation in a $1: 1$ ethanol: toluene solvent system. Strips were scanned for distribution of radioactivity. Ninety-five to 98 per cent of the activity migrated with an Rf of 0.95 (15) during the useful life of the isotope.

Isotope counting equipment. The detector is a gammaray-sensitive, bismuth-tube well sufficiently large to contain the human head (Nucleonic Corporation of America). The background count rate with shielding is 2,500 cpm. The well is surrounded by 2 inches of lead, and has a movable lead collar at the orifice that excludes virtually all radiation emanating from below the subject's neck, except for a small region at the base of the neck (Figure 6). The count rate of a dose of either $\mathrm{Rb}^{\mathrm{8} 8}$ or 4-iodo ${ }^{131}$ antipyrine from the orifice in the collar, as compared to the count rate within the well, was less than 2 per cent.

The position of the subject's head within the well is critical, particularly since count rate is inversely proportional to the square of the distance, and the dimensions of this counting system are large. It was necessary to place each subject in the same position as the calibrating phantom, since motion within the well near the orifice where the head and neck were confined altered the count rate significantly.

Count rates were recorded through a linear rate meter (Nuclear-Chicago model 1510A) onto a strip chart recorder at 6 inches per minute (Texas Instrument Company).

Calibrating standard. The standards were prepared by making duplicate injections of the isotopes into $100-\mathrm{ml}$ volumetric flasks through the venous injection catheter (100 per cent standard). A known fraction of the substance for injection was placed in a "standard" waterfilled phantom head (16), and quantification of the cephalic fraction of the injected dose was performed by comparing the cephalic count rates with the count rate of the phantom (Figure 6). In this system, the count rate was relatively independent of the isotope distribution within the phantom. For example, when $\mathrm{Rb}^{88}$ was placed in the periphery of the phantom, with the center portion taken up by a water-filled balloon, the count rates were not different. This is probably the result of several simultaneously operating variables such as changes in

\footnotetext{
${ }^{1}$ Obtained from Abbott Laboratories, North Chicago, III. 2 Dosimetry:

$T$ eff. (days)

$q(R=3 \mathrm{rem} / 13$ weeks $)$

$q(R=0.1 \mathrm{rem} /$ week $)$
}

distance, radiation absorption and scattering in the fluid medium, and end loss from the detector.

The phantom, however, was not satisfactory unless it contained a neck piece, since 20 per cent of the total counts observed within the well were counted in a sample placed externally in the position of the neck. Although the size of the phantom takes no account of individual variations in head size, fluid volumes from 4 to $6 \mathrm{~L}$ had no effect upon the total count rate. Uneven isotope distribution within the human brain, however, may contribute to error in quantification of the cephalic flow fraction. This will require further evaluation, particularly in disease states where large areas may lack adequate perfusion.

Cardiac output. Cardiac output was measured by use of the indicator dilution principle (17) by direct arterial sampling through a linear photodensitometer (Guilford Instrument Company) with indocyanine as the indicator. Cardiac output was determined before and immediately after measurement of cephalic fractions. The results were averaged for the final calculations.

Blood gases. Oxygen content, oxygen capacity, and carbon dioxide content were determined on arterial blood samples during each procedure with duplicate checks within 0.2 vol per cent by the manometric technique of Van Slyke and Neill (18). Arterial pH was measured with a Cambridge model $\mathrm{R} \mathrm{pH}$-meter and corrected to body temperature with Rosenthal's factor (19). Arterial $\mathrm{pCO}_{2}$ was calculated from the line graph of Van Slyke and Sendroy (20).

Arterial pressure and vasiular resistance. Mean arterial pressure was recorded with the reference point in the second intercostal space at the mid-chest with a Statham p23G strain gauge coupled to a carrier amplifier and direct-writing recorder (Sanborn model 150).

Total peripheral resistance (TPR) was calculated from the following relationship: TPR (dyne-sec- $\mathrm{cm}^{-5}$ ) $=$ [Mean arterial blood pressure $(\mathrm{mm} \mathrm{Hg}) \times 1,332$ ]/ cardiac output ( $\mathrm{ml}$ per $\mathrm{sec}$ ). The contribution of left atrial pressure was ignored (21). Cerebral vascular resistance was calculated from a similar relationship by substituting cerebral blood flow in milliliters per second for cardiac output and omitting the correction for jugular venous pressure.

\section{RESULTS}

Table I shows the results for cerebral blood flow with the isotope technique in 16 resting male patients. Normal values are demonstrated for arterial oxygen saturation, serum $\mathrm{CO}_{2}$ content (vol per cent), arterial $\mathrm{pH}$, and calculated $\mathrm{pCO}_{2}$. The total cephalic flow fraction determined from the zero time extrapolation of the cephalic 4-iodo ${ }^{131}$ antipyrine content was $21.4 \pm 3.6$ per cent of the injected dose. The noncerebral cephalic fraction of the injected dose, not corrected for the cerebral $\mathrm{Rb}^{86}$ reservoir, was $10.0 \pm 1.7$ per cent 
TABLE I

Cerebral blood flow-resting values in normal patients

\begin{tabular}{|c|c|c|c|c|c|c|c|c|c|c|c|}
\hline \multirow[b]{2}{*}{ Subject } & \multirow[b]{2}{*}{ Age } & \multirow[b]{2}{*}{$\begin{array}{l}\text { Body } \\
\text { surface } \\
\text { area }\end{array}$} & \multicolumn{4}{|c|}{ Arterial blood gases } & \multicolumn{5}{|c|}{ Cerebral circulation } \\
\hline & & & Sat. & $\underset{\mathrm{CO}_{2}}{\text { Serum }}$ & $\mathrm{pH}$ & $\mathrm{pCO}_{2}$ & $\begin{array}{l}\text { Cephalic } \\
\text { fraction }\end{array}$ & $\begin{array}{l}\text { Non- } \\
\text { cerebral } \\
\text { cephalic } \\
\text { fraction }\end{array}$ & $\begin{array}{l}\text { Cor- } \\
\text { rected } \\
\text { cerebral } \\
\text { fraction }\end{array}$ & $\begin{array}{c}\text { Cardiac } \\
\text { output }\end{array}$ & $\begin{array}{l}\text { Cerebral } \\
\text { blood } \\
\text { flow }\end{array}$ \\
\hline & & $m^{2}$ & $\%$ & vol\% & & $m m H g$ & $\%$ & $\%$ & $\%$ & $L / \min$ & $m l / m i n$ \\
\hline H.M. & 38 & 1.98 & 93.7 & 63.5 & 7.40 & 46 & 19.6 & 8.9 & 11.6 & 5.15 & 597 \\
\hline G.F. & 38 & 1.98 & 94.9 & 54.9 & 7.37 & 43 & 23.9 & 12.0 & 13.3 & 6.21 & 825 \\
\hline G.J. & 37 & 1.77 & 96.0 & 61.5 & 7.41 & 44 & 20.0 & 7.0 & 13.9 & 5.59 & 777 \\
\hline H.P. & 41 & 2.15 & 96.0 & 53.2 & 7.40 & 39 & 16.5 & 8.2 & 9.0 & 6.11 & 550 \\
\hline J.O. & 41 & 1.71 & 99.7 & 53.5 & 7.41 & 38 & 20.1 & 10.0 & 11.1 & 5.97 & 663 \\
\hline H.B. & 40 & 1.84 & 95.8 & 57.2 & 7.40 & 42 & 22.5 & 11.3 & 12.4 & 4.36 & 541 \\
\hline A.B. & 29 & 1.80 & 97.3 & 57.0 & 7.41 & 41 & 24.3 & 10.8 & 14.9 & 5.71 & 851 \\
\hline D.J. & 36 & 1.80 & 97.5 & 50.1 & 7.41 & 36 & 14.9 & 8.6 & 6.7 & 6.34 & 425 \\
\hline J.B. & 28 & 1.76 & 97.3 & 55.0 & 7.39 & 41 & 26.6 & 13.5 & 15.3 & 5.99 & 874 \\
\hline H.P. & 30 & 1.72 & 96.1 & 54.8 & 7.37 & 43 & 23.8 & 10.7 & 14.5 & 6.10 & 885 \\
\hline J.K. & 42 & 1.83 & 94.1 & 52.9 & 7.39 & 39 & 20.0 & 10.0 & 11.0 & 4.86 & 535 \\
\hline S.J. & 33 & 1.68 & 98.2 & 62.2 & 7.41 & 44 & 25.9 & 11.0 & 16.4 & 5.99 & 982 \\
\hline W.S. & 27 & 1.84 & 98.2 & 54.0 & 7.42 & 38 & 18.6 & 8.4 & 11.0 & 5.07 & 558 \\
\hline R.S. & 24 & 1.73 & 94.4 & 58.5 & 7.37 & 45 & 22.2 & 9.4 & 14.0 & 5.85 & 819 \\
\hline M.J. & 36 & 1.69 & 94.5 & 54.4 & 7.42 & 38 & 25.8 & 11.2 & 16.2 & 5.79 & 938 \\
\hline R.E. & 44 & 1.96 & 99.7 & 58.0 & 7.40 & 42 & 17.1 & 8.9 & 8.9 & 5.96 & 530 \\
\hline Mean & 35 & 1.83 & 96.5 & 56.3 & 7.40 & 40.6 & 21.4 & 10.0 & 12.5 & 5.69 & 709 \\
\hline $\mathrm{SD}$ & \pm 5.8 & \pm .13 & \pm 1.8 & \pm 4.0 & \pm .016 & \pm 2.9 & \pm 3.6 & \pm 1.7 & \pm 2.8 & \pm .53 & \pm 178 \\
\hline
\end{tabular}

of the injected $\mathrm{Rb}^{86}$. The cerebral fraction of the $\mathrm{Rb}^{86}$ shunt, was $12.5 \pm 2.8$ per cent of the cardiac cardiac output, as the difference between the total cephalic fraction and the noncerebral cephalic fracoutput. Mean cardiac output for this group was tion corrected for the redistribution of the cerebra $5.69 \pm 0.53 \mathrm{~L}$ per min. The total cerebral blood flow, as the product of the cardiac output and the

TABLE II

Cerebral blood flow-replicate resting determinations

\begin{tabular}{|c|c|c|c|c|c|c|c|c|c|}
\hline \multirow[b]{2}{*}{ Control } & \multicolumn{4}{|c|}{ Arterial blood gases } & \multicolumn{5}{|c|}{ Cerebral circulation } \\
\hline & Sat. & $\begin{array}{l}\text { Serum } \\
\mathrm{CO}_{2}\end{array}$ & $\mathrm{pH}$ & $\mathrm{pCO}_{2}$ & $\begin{array}{l}\text { Cephalic } \\
\text { fraction }\end{array}$ & $\begin{array}{l}\text { Non- } \\
\text { cerebral } \\
\text { cephalic } \\
\text { fraction }\end{array}$ & $\begin{array}{l}\text { Cor- } \\
\text { rected } \\
\text { cerebral } \\
\text { fraction }\end{array}$ & $\begin{array}{l}\text { Cardiac } \\
\text { output }\end{array}$ & $\begin{array}{l}\text { Cerebral } \\
\text { blood flow }\end{array}$ \\
\hline I. & $\%$ & vol\% & & $m m \mathrm{Hg}$ & $\%$ & $\%$ & $\%$ & $L / \min$ & $m l / m i n$ \\
\hline $\begin{array}{l}\text { A.B. } \\
\text { D.J. } \\
\text { J.K. } \\
\text { S.J. } \\
\text { R.S. }\end{array}$ & $\begin{array}{l}97.3 \\
97.5 \\
94.1 \\
98.2 \\
94.4\end{array}$ & $\begin{array}{l}57.0 \\
50.1 \\
52.9 \\
62.2 \\
58.5\end{array}$ & $\begin{array}{l}7.41 \\
7.41 \\
739 \\
7.41 \\
7.37\end{array}$ & $\begin{array}{l}41 \\
36 \\
39 \\
44 \\
45\end{array}$ & $\begin{array}{l}24.3 \\
14.9 \\
200 \\
25.9 \\
22.2\end{array}$ & $\begin{array}{r}10.8 \\
8.6 \\
10.0 \\
11.0 \\
9.4\end{array}$ & $\begin{array}{r}14.9 \\
6.7 \\
11.0 \\
16.4 \\
14.0\end{array}$ & $\begin{array}{l}5.71 \\
6.34 \\
4.86 \\
5.99 \\
5.85\end{array}$ & $\begin{array}{l}851 \\
425 \\
535 \\
982 \\
819\end{array}$ \\
\hline $\begin{array}{l}\text { Mean } \\
\text { Sample SD }\end{array}$ & $\begin{array}{r}96.3 \\
\pm 1.9\end{array}$ & $\begin{array}{r}56.1 \\
\pm 4.7\end{array}$ & $\begin{array}{l}7.40 \\
\pm .018\end{array}$ & $\begin{array}{l}41 \\
\pm 3.7\end{array}$ & $\begin{array}{r}21.5 \\
\pm 4.3\end{array}$ & $\begin{array}{r}9.9 \\
\pm 1.0\end{array}$ & $\begin{array}{r}12.6 \\
\pm 3.8\end{array}$ & $\begin{array}{r}5.75 \\
\pm .55\end{array}$ & $\begin{array}{r}722 \\
\pm 232\end{array}$ \\
\hline $\begin{array}{ll} & \text { II. } \\
\text { A.B. } & \\
\text { D.J. } & \\
\text { J.K. } & \\
\text { S.J. } & \\
\text { R.S. } & \end{array}$ & $\begin{array}{l}95.3 \\
95.0 \\
91.6 \\
98.0 \\
95.7\end{array}$ & $\begin{array}{l}55.1 \\
49.4 \\
55.5 \\
57.9 \\
58.6\end{array}$ & $\begin{array}{l}7.41 \\
7.42 \\
7.40 \\
7.42 \\
7.37\end{array}$ & $\begin{array}{l}39 \\
34 \\
41 \\
40 \\
46\end{array}$ & $\begin{array}{l}25.3 \\
15.8 \\
19.1 \\
25.8 \\
21.8\end{array}$ & $\begin{array}{r}11.3 \\
8.3 \\
10.4 \\
10.5 \\
7.9\end{array}$ & $\begin{array}{r}15.5 \\
7.6 \\
9.6 \\
16.6 \\
14.9\end{array}$ & $\begin{array}{l}5.99 \\
6.08 \\
4.36 \\
5.48 \\
5.94\end{array}$ & $\begin{array}{l}928 \\
462 \\
419 \\
910 \\
885\end{array}$ \\
\hline $\begin{array}{l}\text { Mean } \\
\text { Sample SD }\end{array}$ & $\begin{array}{r}95.1 \\
\pm 2.3\end{array}$ & $\begin{array}{r}55.3 \\
\pm 3.6\end{array}$ & $\begin{array}{l}7.40 \\
\pm .021\end{array}$ & $\begin{array}{l}40 \\
\pm 4.3\end{array}$ & $\begin{array}{r}21.6 \\
\pm 4.2\end{array}$ & $\begin{array}{r}9.7 \\
\pm 1.5\end{array}$ & $\begin{array}{r}12.8 \\
\pm 4.0\end{array}$ & $\begin{array}{r}5.57 \\
\pm .71\end{array}$ & $\begin{array}{r}721 \\
\pm 256\end{array}$ \\
\hline $\begin{array}{l}\text { Coefficient of } \\
\text { correlation }(r)\end{array}$ & .90 & .85 & .86 & .82 & .98 & .89 & .96 & .88 & .96 \\
\hline$t$ Test & $<.001$ & $<.01$ & $<.01$ & $<.01$ & $<.001$ & $<.001$ & $<.001$ & $<.001$ & $<.001$ \\
\hline
\end{tabular}


TABLE III

Cerebral blood flow-hyperventilation compared to control values

\begin{tabular}{|c|c|c|c|c|c|c|c|c|c|}
\hline & \multicolumn{4}{|c|}{ Arterial blood gases } & \multicolumn{5}{|c|}{ Cerebral circulation } \\
\hline & Sat. & $\begin{array}{l}\text { Serum } \\
\mathrm{CO}_{2}\end{array}$ & $\mathrm{pH}$ & $\mathrm{pCO}_{2}$ & $\begin{array}{l}\text { Cephalic } \\
\text { fraction }\end{array}$ & $\begin{array}{l}\text { Non- } \\
\text { cerebral } \\
\text { cephalic } \\
\text { fraction }\end{array}$ & $\begin{array}{l}\text { Cor- } \\
\text { rected } \\
\text { cerebral } \\
\text { fraction }\end{array}$ & $\begin{array}{l}\text { Cardiac } \\
\text { output }\end{array}$ & $\begin{array}{l}\text { Cerebral } \\
\text { blood flow }\end{array}$ \\
\hline Control & $\%$ & vol\% & & $m m \mathrm{Hg}$ & $\%$ & $\%$ & $\%$ & $L / \min$ & $m l / m i n$ \\
\hline $\begin{array}{l}\text { H.M. } \\
\text { G.F. } \\
\text { G.J. } \\
\text { J.O. } \\
\text { H.B. }\end{array}$ & $\begin{array}{l}93.7 \\
94.9 \\
96.0 \\
99.7 \\
95.8\end{array}$ & $\begin{array}{l}63.5 \\
54.9 \\
61.5 \\
53.5 \\
57.2\end{array}$ & $\begin{array}{l}7.40 \\
7.37 \\
7.41 \\
7.41 \\
7.40\end{array}$ & $\begin{array}{l}46 \\
33 \\
44 \\
38 \\
42\end{array}$ & $\begin{array}{l}19.6 \\
23.9 \\
20.0 \\
20.1 \\
22.5\end{array}$ & $\begin{array}{r}8.9 \\
12.0 \\
7.0 \\
10.0 \\
11.3\end{array}$ & $\begin{array}{l}11.6 \\
13.3 \\
13.9 \\
11.1 \\
12.4\end{array}$ & $\begin{array}{l}5.15 \\
6.21 \\
5.59 \\
5.97 \\
4.36\end{array}$ & $\begin{array}{l}597 \\
825 \\
777 \\
663 \\
541\end{array}$ \\
\hline $\begin{array}{l}\text { Mean } \\
\text { Sample SD }\end{array}$ & $\begin{array}{r}96.1 \\
\pm 2.2\end{array}$ & $\begin{array}{r}58.1 \\
\pm 4.3\end{array}$ & $\begin{array}{l}7.40 \\
\pm .016\end{array}$ & $\begin{array}{c}41 \\
\pm 5.2\end{array}$ & $\begin{array}{r}21.2 \\
\pm 1.9\end{array}$ & $\begin{array}{r}9.8 \\
\pm 2.5\end{array}$ & $\begin{array}{r}12.5 \\
\pm 1.2\end{array}$ & $\begin{array}{r}5.46 \\
\pm 0.73\end{array}$ & $\begin{array}{r}681 \\
\pm 119\end{array}$ \\
\hline $\begin{array}{l}\text { Hyperventilation } \\
\text { H.M. } \\
\text { G.F. } \\
\text { G.J. } \\
\text { J.O. } \\
\text { H.B. }\end{array}$ & $\begin{array}{l}98.9 \\
97.4 \\
98.7 \\
95.9 \\
98.1\end{array}$ & $\begin{array}{l}51.7 \\
40.0 \\
42.6 \\
41.1 \\
46.2\end{array}$ & $\begin{array}{l}7.63 \\
7.59 \\
7.59 \\
7.61 \\
7.59\end{array}$ & $\begin{array}{l}24 \\
14 \\
20 \\
19 \\
22\end{array}$ & $\begin{array}{l}12.5 \\
20.8 \\
13.9 \\
12.5 \\
17.5\end{array}$ & $\begin{array}{r}9.0 \\
12.7 \\
6.5 \\
8.6 \\
12.0\end{array}$ & $\begin{array}{l}3.6 \\
9.2 \\
7.9 \\
4.5 \\
6.2\end{array}$ & $\begin{array}{l}6.07 \\
7.80 \\
6.63 \\
6.75 \\
5.33\end{array}$ & $\begin{array}{l}219 \\
718 \\
524 \\
304 \\
330\end{array}$ \\
\hline $\begin{array}{l}\text { Mean } \\
\text { Sample SD }\end{array}$ & $\begin{array}{r}97.8 \\
\pm 1.2\end{array}$ & $\begin{array}{r}44.3 \\
\pm 4.7\end{array}$ & $\begin{array}{l}7.60 \\
\pm .057\end{array}$ & $\begin{array}{l}20 \\
\pm 3.8\end{array}$ & $\begin{array}{r}15.4 \\
\pm 3.7\end{array}$ & $\begin{array}{r}9.8 \\
\pm 2.6\end{array}$ & $\begin{array}{r}6.3 \\
\pm 2.3\end{array}$ & $\begin{array}{r}6.52 \\
\pm .58\end{array}$ & $\begin{array}{r}419 \\
\pm 201\end{array}$ \\
\hline$t$ Test & NS & $<.005$ & $<.005$ & $<.005$ & $<.005$ & NS & $<.005$ & $<.005$ & $<.005$ \\
\hline
\end{tabular}

cerebral fraction of the cardiac output, averaged $709 \pm 178 \mathrm{ml}$ per min. These results agree with those reported by use of the Kety-Schmidt nitrous oxide method $(2,22)$.

Table II demonstrates the reliability of the de- measured is presented with the $t$ test of significance

Cerebral blood flow-5 per cent $\mathrm{CO}_{2}$ compared with control values

\begin{tabular}{|c|c|c|c|c|c|c|c|c|c|}
\hline & \multicolumn{4}{|c|}{ Arterial blood gases } & \multicolumn{5}{|c|}{ Cerebral circulation } \\
\hline & Sat. & $\begin{array}{c}\text { Serum } \\
\mathrm{CO}_{2}\end{array}$ & $\mathrm{pH}$ & $\mathrm{pCO}_{2}$ & $\begin{array}{l}\text { Cephalic } \\
\text { fraction }\end{array}$ & $\begin{array}{l}\text { Non- } \\
\text { cerebral } \\
\text { cephalic } \\
\text { fraction }\end{array}$ & $\begin{array}{l}\text { Cor- } \\
\text { rected } \\
\text { cerebral } \\
\text { fraction }\end{array}$ & $\begin{array}{l}\text { Cardiac } \\
\text { output }\end{array}$ & $\begin{array}{c}\text { Cerebral } \\
\text { blood flow }\end{array}$ \\
\hline Control & $\%$ & vol\% & & $m m \mathrm{Hg}$ & $\%$ & $\%$ & $\%$ & $L / \min$ & $m l / m i n$ \\
\hline $\begin{array}{l}\text { J.B. } \\
\text { H.P. } \\
\text { W.S. } \\
\text { R.E. } \\
\text { M.J. }\end{array}$ & $\begin{array}{l}97.3 \\
96.1 \\
98.2 \\
99.7 \\
94.5\end{array}$ & $\begin{array}{l}55.0 \\
54.9 \\
54.0 \\
58.0 \\
54.4\end{array}$ & $\begin{array}{l}7.39 \\
7.37 \\
7.42 \\
7.40 \\
7.42\end{array}$ & $\begin{array}{l}41 \\
43 \\
38 \\
41 \\
38\end{array}$ & $\begin{array}{l}26.6 \\
23.8 \\
18.6 \\
17.1 \\
25.8\end{array}$ & $\begin{array}{r}13.5 \\
10.7 \\
8.4 \\
8.9 \\
11.2\end{array}$ & $\begin{array}{r}15.3 \\
14.5 \\
11.0 \\
8.9 \\
16.2\end{array}$ & $\begin{array}{l}5.99 \\
6.10 \\
5.07 \\
5.96 \\
5.79\end{array}$ & $\begin{array}{l}874 \\
885 \\
558 \\
530 \\
938\end{array}$ \\
\hline $\begin{array}{l}\text { Mean } \\
\text { Sample SD }\end{array}$ & $\begin{array}{r}97.2 \\
\pm 2.0\end{array}$ & $\begin{array}{r}55.3 \\
\pm 1.6\end{array}$ & $\begin{array}{l}7.40 \\
\pm .021\end{array}$ & $\begin{array}{l}40 \\
\pm 2.2\end{array}$ & $\begin{array}{r}22.4 \\
\pm 4.3\end{array}$ & $\begin{array}{r}10.5 \\
\pm 2.0\end{array}$ & $\begin{array}{r}13.2 \\
\pm 3.1\end{array}$ & $\begin{array}{c}5.78 \\
\pm 0.41\end{array}$ & $\begin{array}{r}757 \\
\pm 196\end{array}$ \\
\hline $\begin{array}{l}5 \text { per cent } \mathrm{CO}_{2} \\
\text { J.B. } \\
\text { H.P. } \\
\text { W.S. } \\
\text { R.E. } \\
\text { M.J. }\end{array}$ & $\begin{array}{l}98.0 \\
96.8 \\
97.0 \\
99.0 \\
98.8\end{array}$ & $\begin{array}{l}57.8 \\
57.0 \\
55.5 \\
56.5 \\
55.5\end{array}$ & $\begin{array}{l}7.34 \\
7.33 \\
7.36 \\
7.37 \\
7.40\end{array}$ & $\begin{array}{l}48 \\
49 \\
44 \\
44 \\
40\end{array}$ & $\begin{array}{l}26.4 \\
25.2 \\
23.1 \\
18.5 \\
26.7\end{array}$ & $\begin{array}{r}11.3 \\
11.1 \\
11.8 \\
8.9 \\
11.2\end{array}$ & $\begin{array}{l}16.7 \\
15.6 \\
12.6 \\
10.4 \\
17.1\end{array}$ & $\begin{array}{l}7.16 \\
6.02 \\
5.92 \\
6.07 \\
5.94\end{array}$ & $\begin{array}{r}1196 \\
939 \\
746 \\
631 \\
1016\end{array}$ \\
\hline $\begin{array}{l}\text { Mean } \\
\text { Sample SD }\end{array}$ & $\begin{array}{r}97.9 \\
\pm 1.0\end{array}$ & $\begin{array}{r}56.5 \\
\pm 1.0\end{array}$ & $\begin{array}{l}7.36 \\
\pm .087\end{array}$ & $\begin{array}{l}45 \\
\pm 3.6\end{array}$ & $\begin{array}{r}24.0 \\
\pm 3.4\end{array}$ & $\begin{array}{r}10.9 \\
\pm 1.1\end{array}$ & $\begin{array}{r}14.5 \\
\pm 2.9\end{array}$ & $\begin{array}{r}6.22 \\
\pm .53\end{array}$ & $\begin{array}{r}906 \\
\pm 223\end{array}$ \\
\hline$t$ Test & NS & $<.01$ & $<.01$ & $<.005$ & $<.05$ & $\mathrm{NS}$ & $<.005$ & $<.05$ & $<.005$ \\
\hline
\end{tabular}


TABLE V

Effects of voluntary hyperventilation and 5 per cent $\mathrm{CO}_{2}$ inhalation upon total peripheral resistance and cerebral vascular resistance*

\begin{tabular}{|c|c|c|c|c|}
\hline & $\begin{array}{l}\text { Total } \\
\text { peripheral } \\
\text { resistance }\end{array}$ & $\mathrm{p}$ & $\begin{array}{c}\text { Cerebral } \\
\text { vascular } \\
\text { resistance }\end{array}$ & \\
\hline & dyne-sec- $\mathrm{cm}^{-5}$ & & dyne- & \\
\hline $\begin{array}{l}\text { Control } \dagger \\
\text { Hyperventilation }\end{array}$ & $\begin{array}{l}1,291 \pm 66 \\
1,135 \pm 159\end{array}$ & $<0.05$ & $\begin{array}{l}10,452 \pm 1,691 \\
20,313 \pm 9,048\end{array}$ & $<0.0$ \\
\hline $\begin{array}{l}\text { Control } \dagger \\
5 \text { per cent } \mathrm{CO}_{2}\end{array}$ & $\begin{array}{l}1,329 \pm 239 \\
1,300 \pm 231\end{array}$ & NS & $\begin{array}{r}11,051 \pm 4,746 \\
9,601 \pm 3,534\end{array}$ & $<0$. \\
\hline
\end{tabular}

* Values are means $\pm \mathrm{SD} ; \mathrm{N}=5$ in each group mean. $\dagger$ Differences between controls are not significant.

for the coefficients (23). The results in the same individual are reproducible in the resting state.

Tables III, IV, and V show the effects of altered arterial $\mathrm{pCO}_{2}$ upon cardiac output and cerebral hemodynamics. Voluntary hyperventilation diminished mean arterial $\mathrm{pCO}_{2}$ to $20 \mathrm{~mm} \mathrm{Hg}$ and increased arterial $\mathrm{pH}$ to 7.60. Cardiac output significantly increased $1.06 \mathrm{~L}$ per minute, and the cerebral fraction of the cardiac output was reduced from a normal value of $12.5 \pm 1.2$ to $6.3 \pm 2.3$ per cent. The cerebral blood flow fell from $681 \pm 119$ to $419 \pm 201 \mathrm{ml}$ per minute. Although total peripheral resistance fell slightly, the cerebrovascular resistance approximately doubled. Inhaling 5 per cent $\mathrm{CO}_{2}$ in air for 10 minutes increased arterial $\mathrm{pCO}_{2} 5 \mathrm{~mm} \mathrm{Hg}$ and cardiac output $440 \mathrm{ml}$ per minute. The cerebral fraction of the cardiac output increased from $13.2 \pm 3.1$ to $14.5 \pm 2.9$ per cent. Thus the cerebral blood flow increased from $757 \pm 196$ to $906 \pm 223 \mathrm{ml}$ per minute. The results for $\mathrm{CO}_{2}$ inhalation demonstrate an increase in total cerebral blood flow as well as a greater cerebral distribution of the cardiac output. Although total vascular resistance remained essentially unchanged, there was a decrease in cerebrovascular resistance. The significance of the observed differences was determined with each subject serving as his own control (22).

\section{DISCUSSION}

The exchangeable cephalic reservoir for 4-iodo ${ }^{131}$ antipyrine is sufficiently large that early net redistribution is slow, and the initial washout can be readily extrapolated toward zero time of organ localization. The fact that 4 -iodo ${ }^{131}$ antipyrine does not equilibrate with body water, but is concentrated in the liver (24), probably does not alter the initial arterial distribution during the first minute after injection. Sapirstein has reported (8) that the cephalic uptake of 4-iodo ${ }^{131}$ antipyrine remains relatively constant in man after initial localization, thereby simplifying the extrapolation to maximal organ content. This is presumed to be due to the similarity of the cephalic extraction ratio and the extraction ratio for the rest of the body rather than to zero washout. In preliminary studies in resting subjects, the values reported for the cerebral fraction of the cardiac output could not be confirmed without using a shielded well and a geometrically proportioned phantom head and neck. Lack of suitable shielding (8) also obscured the cephalic washout, demonstrated in all studies reported here, by failing to exclude the body contribution to the well. The concept of similar extraction ratios for the head and body does not appear to be experimentally correct nor theoretically sound. This circumstance could only occur at a unique combination of flow rates. Alterations in flow rates to any organ, or different combinations of flow rates in different subjects would probably disturb any balance that might exist coincidentally. Only in the situation where organs could appropriately change their extraction ratios with changes in flow would equal extraction by head and body be likely to be meaningful, and there is no evidence that this phenomenon occurs.

It would seem more reasonable to describe the relatively slow net redistribution of the cephalic indicator content in terms of the size of the exchangeable pool available for dispersion of 4-iodo ${ }^{131}$ antipyrine. The volume of distribution is considerably greater than the volume of the vascular compartment, and the cephalic distribution pool is considerably larger than the available pool within the vascular compartment perfusing the head at any one time. Thus, the washout rate would reasonably depend upon several factors, including the rate of perfusion, the arterial concentration of indicator, and the relative pool sizes available within the exchanging regions of the organ and the vascular compartment perfusing those regions.

To simplify the calculation of maximal cephalic content, $A_{0}$, of 4 -iodo ${ }^{131}$ antipyrine at zero time, we elected to use the graphical approximation that introduced a 2.5 per cent error in the calculation. 
Recalculation of the control values for cerebral blood flow in 16 subjects from the formulation of the true, maximal 4-iodo ${ }^{1: 1}$ antipyrine content reduced the cephalic fraction from 21.4 to 20.9 per cent of the cardiac output. The mean total flow was reduced to 667 from $709 \mathrm{ml}$ per min. This lower value agrees with the estimates made by the nitrous oxide method with extrapolation to infinite time (25).

At present, the major experimentally unvalidated assumption involves the empirical acceptance of negligible loss or rapid destruction of the 4-iodo ${ }^{131}$ antipyrine during the initial pulmonary passage. Since the pulmonary reservoir in general is small for most substances, only a modest loss of 4 -iodo ${ }^{131}$ antipyrine probably occurs, even if equilibration with lung tissue is complete. Sapirstein and Hanusek (6) have reported that, at least for the rat, there is a period during the latter part of the first pulmonary 4-iodo ${ }^{131}$ antipyrine passage that the residue represents 7 per cent of the injected dose. He states, however, that this is rapidly washed out. Even a loss this great would only introduce a minimal error in the calculation of total cephalic blood flow. This question is difficult to answer experimentally in man, and has not been effectively evaluated to date. The similarity, however, of the results reported for this study to those reported by an accepted method of estimating human cerebral perfusion tends to confirm the validity of the assumption.

The net redistribution of $\mathrm{Rb}^{86} \mathrm{Cl}$ is sufficiently slow that organ uptake is approximately representative of functional regional perfusion. This appears to be valid for a considerably longer period than for 4-iodo ${ }^{131}$ antipyrine, probably because of the greater extravascular pool for $\mathrm{Rb}^{86}$. The brain is a significant exception, since there is virtually no exchangeable cerebral $\mathrm{Rb}^{86}$ pool $(<0.5$ per cent injected dose). The redistribution of the cerebral $\mathrm{Rb}^{86}$ fraction causes an overestimation of the noncerebral cephalic flow because it is taken up out of proportion to the initial distribution of the cardiac output during subsequent recirculations. To correct for this redistribution, it must be assumed that the brain represents the sole source of this redistribution fraction. This assumption cannot be wholly valid, since there are regions of nervous tissue, with blood supply, not observed by the well. Probally neither the quantity of this tissue nor its rate of perfusion is sufficient for major concern. The correction for the redistribution of $\mathrm{Rb}^{86}$ to the noncerebral cephalic structures represents approximately 10 per cent of the total cephalic $\mathrm{Rb}^{86}$ uptake, and therefore would only slightly alter the final calculations if it were underestimated. The pulmonary indicator losses for $\mathrm{K}^{42}$ and $\mathrm{Rb}^{86}$ have been variously reported between 1.9 and 2.7 per cent of the injected dose in rats, dogs, and rabbits $(6,9,14)$, and therefore represent negligible error.

The values calculated for cerebral blood flow during rest, voluntary hyperventilation, and breathing 5 per cent $\mathrm{CO}_{2}$ in air agree closely with those previously reported by use of the Fick principle and inert gas exchange $(2,22)$. Hyperventilation resulted in a significant decrease in total peripheral vascular resistance. The cerebral vessels exhibit marked vasoconstriction, and total cerebrovascular resistance doubled. Five per cent $\mathrm{CO}_{2}$ inhalation minimally increased cardiac output and did not alter total calculated peripheral resistance. The cerebral resistance vessels dilated, however, as shown by a significant reduction of total cerebrovascular resistance.

This investigation describes a method for rapid, quantitative measurement of total cerebral blood flow as the fraction of the cardiac output. The technique requires the steady state only for the period of data generation. The measurements may be easily repeated. Equipment has been designed that may allow for the simultaneous determination of all three parameters required to determine cerebral flow by this technique. A permanent record could then be produced every $2 \mathrm{~min}$ utes and be reduced electronically to final form.

\section{SUMMARY}

The initial distribution of 4-iodo ${ }^{131}$ antipyrine is used to estimate the total cephalic fraction-brain, head, and neck-of the cardiac output. Since there is no readily exchangeable cerebral $\mathrm{Rb}^{86}$ reservoir, and since there is a large, rapidly exchangeable, noncerebral cephalic pool, the stable cephalic content of $\mathrm{Rb}^{86} \mathrm{Cl}$ corrected for recirculation is used to estimate the noncerebral cephalic fraction-just head and neck-of the cardiac output. The difference between the total cephalic 
flow fraction and the noncerebral cephalic flow fraction represents the total cerebral blood flow fraction, which when multiplied by cardiac output, determines the total cerebral blood flow.

The effects of voluntary hyperventilation and breathing 5 per cent $\mathrm{CO}_{2}$ in air upon cardiac output, cerebral blood flow, and cerebral vascular resistance were evaluated with this technique. Voluntary hyperventilation increased cardiac output, reduced cerebral blood flow, and doubled cerebrovascular resistance. Five per cent $\mathrm{CO}_{2}$ minimally increased cardiac output, increased cerebral blood flow, and significantly reduced cerebrovascular resistance. These results agree with those reported by the nitrous oxide method, but have the advantage of estimating total cerebral blood flow as a fraction of the cardiac output.

\section{ACKNOWLEDGMENT}

The authors wish to acknowledge the helpful cooperation of Dr. Alvin S. Hyde, Acceleration Section, Aerospace Medical Laboratory, Wright Patterson Air Force Base, Ohio, in providing some of the equipment used in this investigation.

\section{REFERENCES}

1. Steiner, S. H., Hsu, K., Oliner, L., and Behnke, R. H. Cerebral blood flow by external isotope counting. Physiologist 1961, 4, 116.

2. Kety, S. S., and Schmidt, C. F. Nitrous oxide method for quantitative determination of cerebral blood flow in man: theory, procedure, and normal values. J. clin. Invest. 1948, 27, 476.

3. Sapirstein, L. A., and Ogden, E. Theoretic limitations of the nitrous oxide method for the determination of regional blood flow. Circulat. Res. 1956, 4, 245.

4. Sapirstein, L. A. Fractionation of the cardiac output of rats with isotopic potassium. Circulat. Res. 1956, 4, 689.

5. Sapirstein, L. A. Regional blood flow by fractional distribution of indicators. Amer. J. Physiol. 1958, 193, 161.

6. Sapirstein, L. A., and Hanusek, G. E. Cerebral blood flow in the rat. Amer. J. Physiol. 1958, 193, 272.

7. Sapirstein, L. A. Determination of blood flow to hand with radio potassium. Fed. Proc. 1958, 17, 141.

8. Sapirstein, L. A. Measurement of cephalic and cerebral blood flow fractions of the cardiac output in man. J. clin. Invest. 1962, 41, 1429.
9. Walker, W. G., and Wilde, W. S. Kinetics of radiopotassium in the circulation. Amer. J. Physiol. 1952, 170, 401.

10. Sapirstein, L. A., and Goodwin, R. S. Measurement of blood flow in the human hand with radioactive potassium. J. appl. Physiol. 1958, 13, 81.

11. Hansen, D. B., quoted by S. S. Kety. Measurement of local blood flow by the exchange of an inert, diffusible substance. Meth. med. Res. 1960, 8, 228.

12. Reinmuth, O. M., and Scheinberg, P. The use of $\mathrm{I}^{131}$ labeled iodoantipyrine in the determination of rapid changes in cerebral blood flow (abstract). Neurol. 1961, 11, 271.

13. Gray's Anatomy of the Human Body. C. M. Goss, Ed. Philadelphia, Lea \& Febiger, 1948.

14. Sheppard, C. W., Overman, R. R., Wilde, W. S., and Sangren, W. C. Disappearance of $\mathrm{K}^{42}$ from the non-uniformly mixed circulation pool in dogs. Circulat. Res. 1953, 1, 284.

15. Talso, P. J., Lahr, T. N., Spafford, N., Ferenzi, G., and Jackson, H. R. O. A comparison of the volume of distribution of antipyrine, $\mathrm{N}$-acetyl-4-aminoantipyrine and $\mathrm{I}^{132}$ 4-iodoantipyrine in human beings. J. Lab. clin. Med. 1955, 46, 619.

16. Hayes, R. L., and Brucer, M. Compartmentalized phantoms for the standard man, adolescent and child. Int. J. appl. Radiat. 1960, 9, 113.

17. Hamilton, W. F., Moore, J. W., Kinsman, J. M., and Spurling, R. G. Simultaneous determination of the pulmonary and systemic circulation times in man and of a figure related to the cardiac output. Amer. J. Physiol. 1928, 84, 338.

18. Van Slyke, D. D., and Neill, J. M. Determination of gases in blood and other solutions by vacuum extraction and manometric measurement. J. biol. Chem. 1924, 61, 523.

19. Rosenthal, T. B. The effect of temperature on $\mathrm{pH}$ of blood and plasma in vitro. J. biol. Chem. 1948, 173, 25.

20. Van Slyke, D. D., and Sendroy, J., Jr. Line charts for graphic calculations by Henderson-Hasselbalch equation and for calculating plasma $\mathrm{CO}_{2}$ content from whole blood content. J. biol. Chem. 1928, 79, 781.

21. Warren, J. V., and Gorlin, R. Calculation of vascular resistance. Meth. med. Res. 1958, 7, 98.

22. Kety, S. S., and Schmidt, C. F. The effects of altered tensions of carbon dioxide and oxygen on cerebral blood flow and cerebral oxygen consumption of normal young men. J. clin. Invest. 1948, 27, 484.

23. $\mathrm{Li}, \mathrm{J}$. C. R. Introduction to Statistical Inference. Ann Arbor, Mich., Edwards Brothers, 1957.

24. Sapirstein, L. A. Distribution of 4-Iodoantipyrine in the rat. Fed. Proc. 1961, 20, 75.

25. Lassen, N. A., and Lane, M. H. Validity of internal jugular blood for study of cerebral blood flow and metabolism. J. appl. Physiol. 1961, 16, 313. 